\title{
Estimated production, catch per unit effort, biological aspects of tuna, skipjack, and small tuna in North Sumatra
}

\author{
Gussasta Levi Arnenda ${ }^{1,2^{*}}$, Fathur Rochman ${ }^{1}$, Arief Wujdi ${ }^{1}$, and Roy Kurniawan ${ }^{1,2}$ \\ ${ }^{1}$ Faculty of Mathematics and Natural Science, Udayana University, Indonesia \\ ${ }^{2}$ Research Institute for Tuna Fisheries, Denpasar, 80334, Indonesia
}

\begin{abstract}
Tuna and like species resources are like other renewable resources. The level of exploitation of these resources dramatically affects their ability to maintain their numbers and abundance in the water. Fishery management policy should be conducted based on a scientific-based approach. This research aims to collect data related to tuna fisheries and the like, including data collection aspects of coaching, the composition of catches, and the biology of tuna catches in 2020. Research location in North Sumatra. The results showed that the estimated value of skipjack tuna (SKJ) of 232,823 tons, yellowfin tuna (YFT) of 23,682 tons, frigate tuna (FRI) is 40,949 tons, and Kawakawa (KAW) is 1,374 tons. SKJ, as of 6.149 samples, have length class 18-60 cmFL, CPUE highest in April and lowest in August. FRI of 1.619 samples with a lengthy class between 17-44 cmFL, CPUE highest in October and lowest in December. YFT of 1.060 samples with a lengthy class 18-60 cm, CPUE highest in April and lowest in March. Kawakawa of the 1.530 samples has length class $25-54 \mathrm{~cm}$, with the highest CPUE in April and lowest in March and July.
\end{abstract}

\section{Introduction}

Indonesia is the second-largest country after China as a producer of capture fisheries products in the world with a total production of more than 6 million tons in 2014, with an average of about 4,7 tons/year (2003-2012) [1] The tuna, tunas, and skipjack (TTS) species group contributed $25 \%$ or around 1,5 million tons in the same year. This value is equivalent to 16 $\%$ of the total world tuna production. Data in 2015 stated that the export volume of Indonesian tuna, tuna, and skipjack commodities reached 172,293 tons with a commodity value of $\$ 584$ million, or around 8 billion rupiah. The primary marine fishery commodities set as export growth targets in the 2010 - 2014 strategic plan are tuna, tunas, and skipjack [2].

Tuna fisheries resources (tuna and like species) are like other renewable resources. The level of exploitation of these resources dramatically affects their ability to maintain their numbers and abundance of water. Fishing pressure on tuna resources has increased in line with the high market demand for commercial tuna species. Maintaining the level of exploitation at a

\footnotetext{
* Corresponding author: gussastaarnenda@gmail.com
} 
level that ensures the sustainability of tuna resources is an absolute must. However, in practice, effective management of tuna resource management is very complicated because tuna resources are high migratory species, which during the migration process are always across different country jurisdictions and the high seas. Therefore no country can unilaterally manage tuna effectively.

Therefore, fisheries management policies should be carried out based on scientific studies (scientific-based approach). Adequate data is needed to analyze the population parameters and stock structure of fish resources in these waters. These factors are vital in conducting stock assessments, especially for highly migratory fish. This data and information are beneficial to provide input for appropriate and sustainable management of fish resources, especially in the Fisheries Management Area (FMA) of Indonesian Waters 572. This study aims to determine the catch estimated, length distribution, and CPUE of skipjack tuna, yellowfin tuna, frigate tuna, and Kawakawa.

\section{Methodology}

\subsection{Study area}

This research was carried out at the Nusantara Fishery Port (PPN) of Sibolga, a particular port for fishers in North Sumatra Province. This port is located on the west coast of North Sumatra Province, overlooking the Indian Ocean. PPN Sibolga is located on Jalan Gatot Subroto, Sarudik District, Central Tapanuli Regency, and geographically it is located at the coordinates of $01^{0} 002^{\prime} 15^{\prime \prime}$ South Latitude $100^{0} 23^{\prime} 34^{\prime \prime}$ East Longitude (Fig. 1).

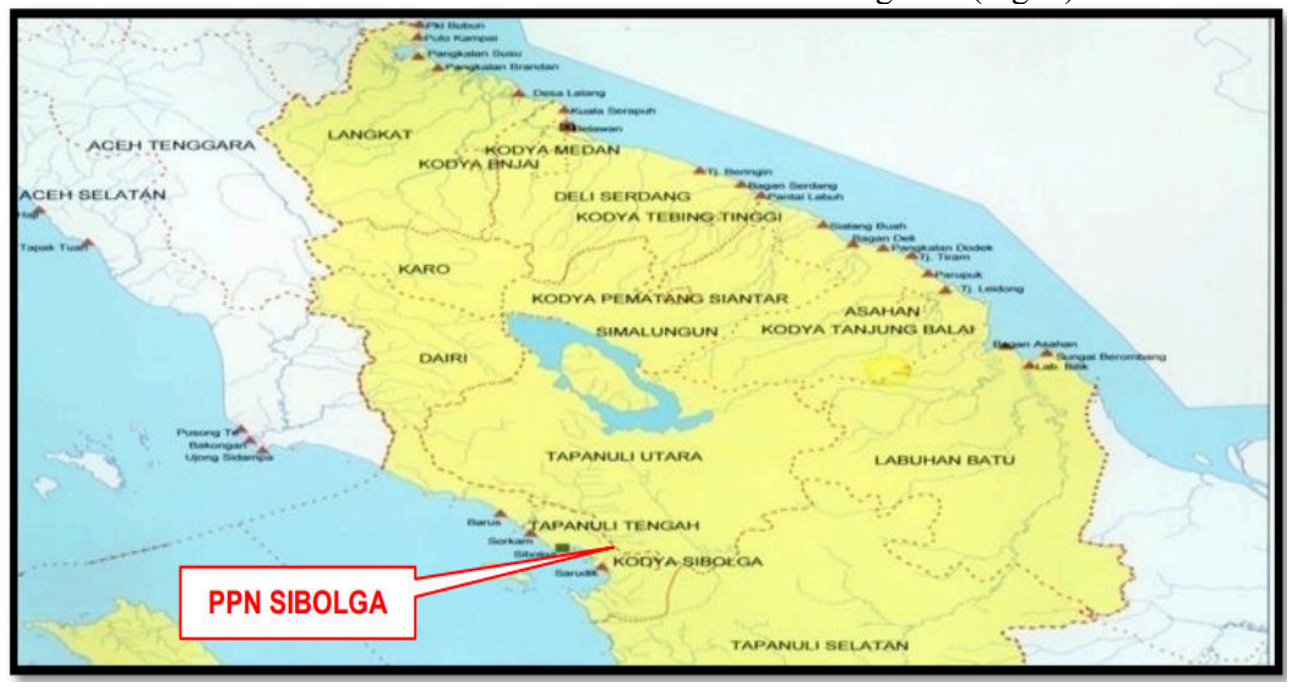

Fig. 1. Nusantara Fishery Port (PPN) of Sibolga.

The study used a meter stratified random sampling system for daily data collection. Data collection was carried out in 2020, except for May and June, due to restrictions in community activities during COVID-19 pandemic. This study also compiles the logbooks and the statistics of the fishing ports. The measurement of bonito fish (Katsuwonus pelamis) (SKJ) was 6,145 samples, yellowfin tuna (Thunnus albacares) (YFT) was 1,040 samples, frigate tuna (Auxis thazard) (FRI) was 1,619 samples, and Kawakawa (Euthynnus affinis) as above to 1,530 samples. 


\subsection{Data analysis}

\subsubsection{Analysis of the length-weight relationship}

The fork length and whole weight relationships were calculated using formula (Effendie, 2002) :

$$
W W=a F L^{b}
$$

WW: Whole Weight (g), FL: Fork Length (cm), a: Intercept, b: Slope

\subsubsection{Catch estimation}

Calculation of estimated catch using the estimation formula from the Indian Ocean Tuna Commission (IOTC, 2002) :

$$
E C=N \times E C V
$$

EC: Estimated catch (tons), N: Number of vessels landing the catch (units), ECV: Enumerated catch (tons) / number of vessels enumerated (units)

\subsubsection{Catch per Unit Effort (CPUE)}

The calculation for Catch per Unit of Effort using formula (Gunarso \& Wiyono, 1994) :

$$
C P U E=\frac{C}{E}
$$

CPUE: Catch per unit of effort, C: Catch (kg), E: Effort (trip)

\section{Results}

This study found that the composition of the catches of fishing vessels that landed at PPN Sibolga contained four species of tuna, skipjack, and small tuna (TCT). The composition of the catch was dominated by skipjack tuna (Katsuwonus pelamis) (SKJ) of 50,11\%, frigate tuna (Auxis thazard) (FRI) of 8,81\%, yellowfin tuna (Thunnus albacares) (YFT) of 5,10\%, and kawakawa (Euthynnus affinis) (KAW) by 0,30\%. The composition of TCT catches based on Sibolga PPN during 2020 is presented in Fig. 2. All species were found from January to December. Skipjack tuna dominates all catches every month, so it is used as the main catch target in PPN Sibolga.

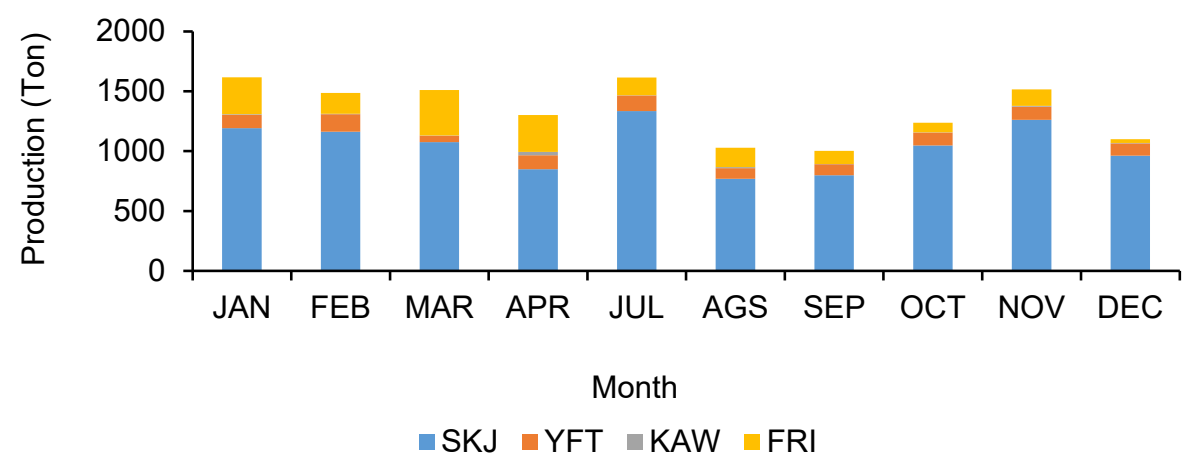

Fig. 2. Catch composition of skipjack tuna, yellowfin tuna, kawakawa, and frigate tuna, from January until December 2020. 
The contribution of sampling data collection to vessels landing their catch at PPN Sibolga is $4-5,29 \%$. The estimated value is obtained from the average number of catches per vessel multiplied by the number of vessels landing each month during the 2020 period. The estimated catch is obtained from 4.122 vessels landing with 185 vessels sampled. The estimated values obtained are: SKJ as much as 232,823 tons, FRI estimated at 40,949 tons, YFT estimated at 23,682 tons, and KAW estimated at 1,374 tons. The percentage contribution of sampling is presented in Table 1.

Table 1. Production estimation of SKJ, YFT, KAW, FRI in PPN Sibolga.

\begin{tabular}{lccccccr}
\hline \multirow{2}{*}{ Month } & \multirow{2}{*}{ Landing } & \multirow{2}{*}{ Sampling } & \multirow{2}{*}{$\boldsymbol{c}$} & \multicolumn{5}{c}{ Estimation (kg) } \\
\cline { 7 - 8 } & & & & SKJ & FRI & \multicolumn{1}{c}{ YFT } & \multicolumn{1}{c}{ KAW } \\
\hline JAN & 464 & 19 & 4,09 & 29.093 & 7.500 & 2.731 & 133 \\
FEB & 454 & 24 & 5,29 & 21.970 & 3.301 & 2.782 & 62 \\
MAR & 471 & 22 & 4,67 & 23.012 & 8.109 & 1.174 & 25 \\
APR & 238 & 10 & 4,20 & 20.194 & 7.327 & 2.795 & 659 \\
MEI & & & & & & & \\
JUN & & & & & & & \\
JUL & 465 & 24 & 5,16 & 25.849 & 2.878 & 2.536 & 33 \\
AUG & 450 & 18 & 4,00 & 19.223 & 4.055 & 2.201 & 243 \\
SEP & 389 & 19 & 4,88 & 16.359 & 2.220 & 1.887 & 44 \\
OCT & 331 & 14 & 4,23 & 24.779 & 1.913 & 2.542 & 21 \\
NOV & 434 & 17 & 3,92 & 32.198 & 3.524 & 2.821 & 144 \\
DEC & 426 & 18 & 4,23 & 22.767 & 746 & 2.428 & 92 \\
\hline Total & $\mathbf{4 . 1 2 2}$ & $\mathbf{1 8 5}$ & $\mathbf{4 , 4 9}$ & $\mathbf{2 3 2 . 8 2 3}$ & $\mathbf{4 0 . 9 4 9}$ & $\mathbf{2 3 . 6 8 2}$ & $\mathbf{1 . 3 7 4}$ \\
\hline
\end{tabular}

Skipjack tuna found in this study were 6.149 samples with a length distribution of 18 - 60 cmFL, dominant length $35 \mathrm{cmFL}$, average length $34 \mathrm{cmFL}$. Overall, the relationship between SKJ length and weight follows the formula $\mathrm{W}=0.0099 * \mathrm{~L}^{3,1867}$ with a coefficient of determination $\left(\mathrm{R}^{2}\right)=0,9263$ (Fig. 3) and t-test results at the $95 \%$ level of confidence; it shows that the growth pattern of SKJ is positive allometric $(b>3)$. This value means that the weight grows faster than the length, making the SKJ look more rounded or fatter. Analysis of catch per unit of effort or CPUE on SKJ obtained the highest in April and October.

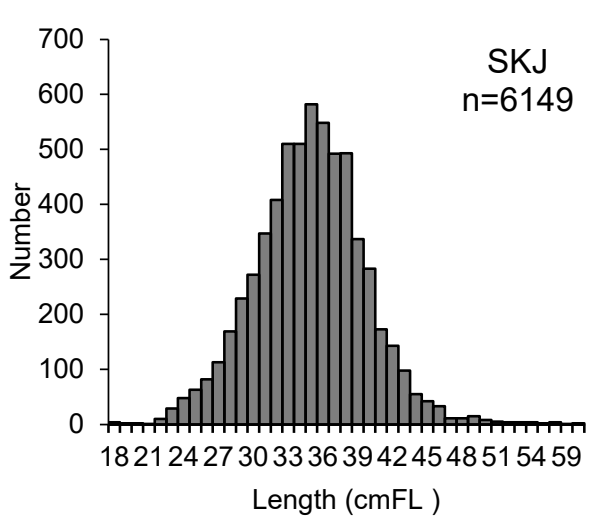

(a)

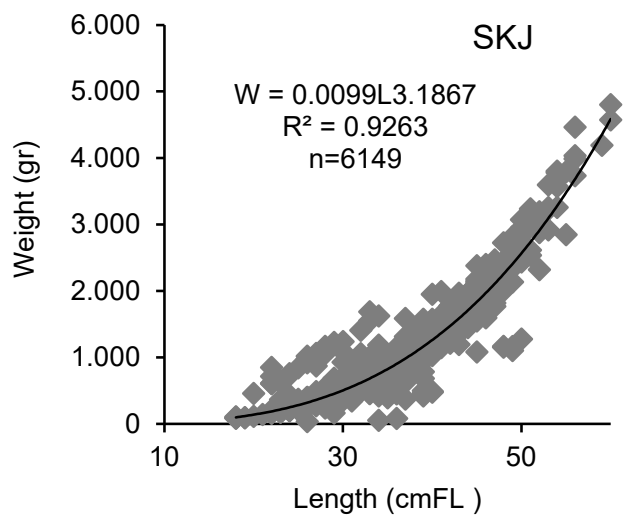

(b) 


\section{SKJ}

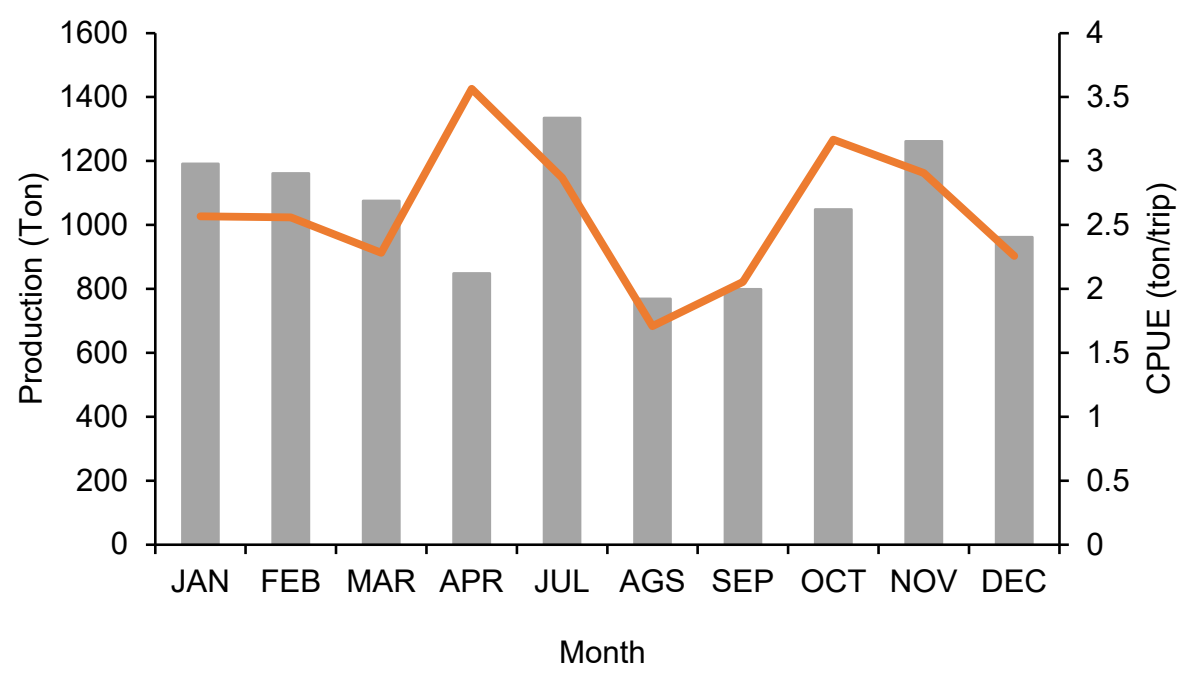

Production (ton) $\longrightarrow$ CPUE (ton/trip)

(c)

Fig. 3. SKJ : (a) Length distribution ; (b) length-weight relationship; (c) CPUE.

Frigate tuna (FRI) found in this study were 1.619 samples with a length distribution of 17-44 cmFL, dominant length $25 \mathrm{cmFL}$, average length $29 \mathrm{cmFL}$. Overall, the relationship between FRI length and weight follows the formula $\mathrm{W}=0,0065 \mathrm{~L}^{3,2865}$ with $\mathrm{R}^{2}$ (coefficient of determination $=0,9583$ (Fig. 4 ) and t-test results at the $95 \%$ level of confidence, it shows that the growth pattern of FRT is positive allometric $(b>3)$. This value means that the weight grows faster than the length, so the FRT looks more rounded or fatter. Analysis of catch per unit of effort or CPUE carried out on FRT obtained the highest in April and October.

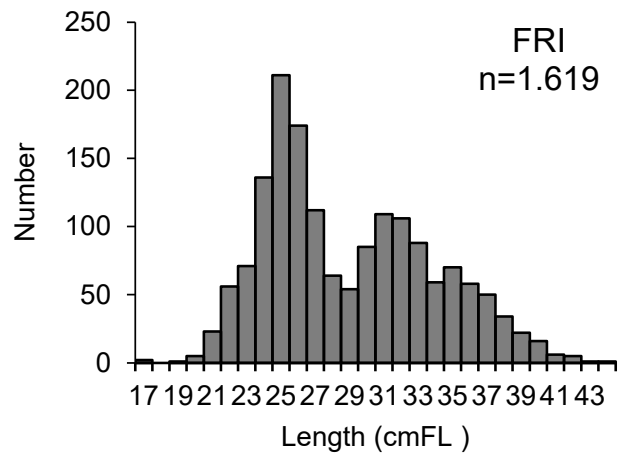

(a)

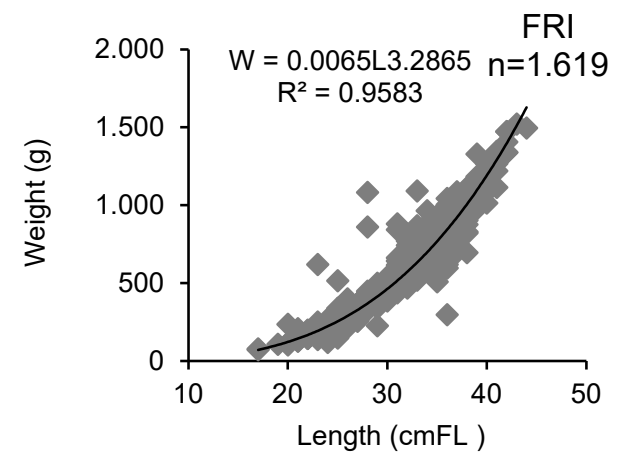

(b) 
Fri

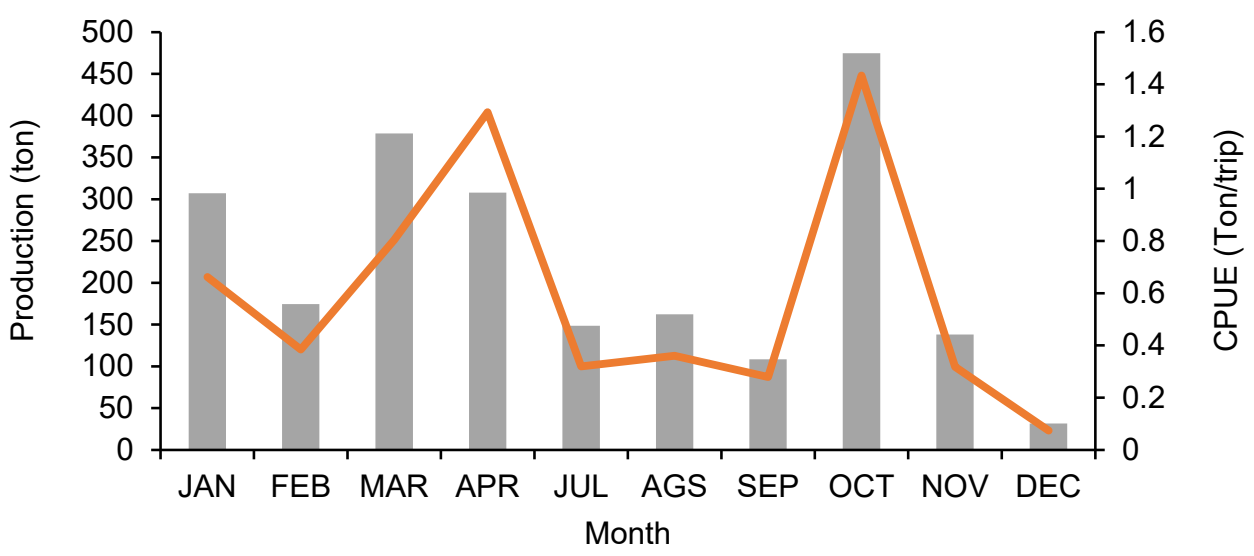

Production (ton) CPUE (ton/trip)

(c)

Fig. 4. FRT : (a) Length distribution; (b) length-weight relationship; (c) CPUE.

Yellowfin tuna (YFT) found in this study were 1.060 samples with a length distribution of 18-60 cmFL, dominant length $36 \mathrm{cmFL}$, average length $36 \mathrm{cmFL}$. Overall, the relationship between YFT length and weight follows the formula $\mathrm{W}=0,0329 \mathrm{~L}^{2,8699}$ with $\mathrm{R}^{2}$ (coefficient of determination) $=0,9414$ (Fig. 5) and t-test results at the $95 \%$ level of confidence, it shows that the growth pattern of YFT is negative allometric $(b<3)$. This value means that the length grows faster than the weight, so the YFT looks slimmer. Analysis of catch per unit of effort or CPUE on YFT obtained the highest in April and October.

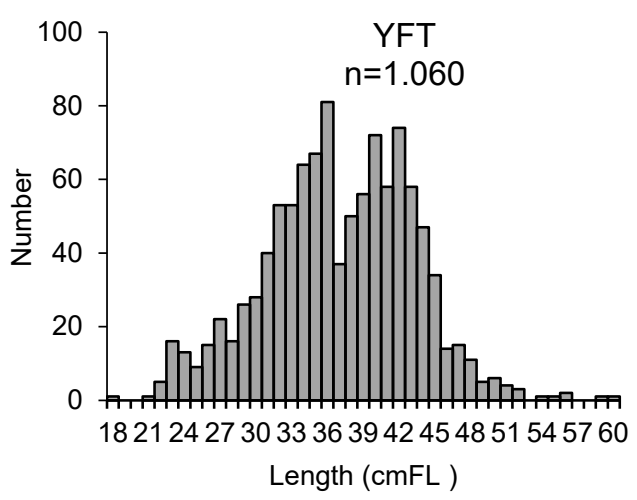

(a)

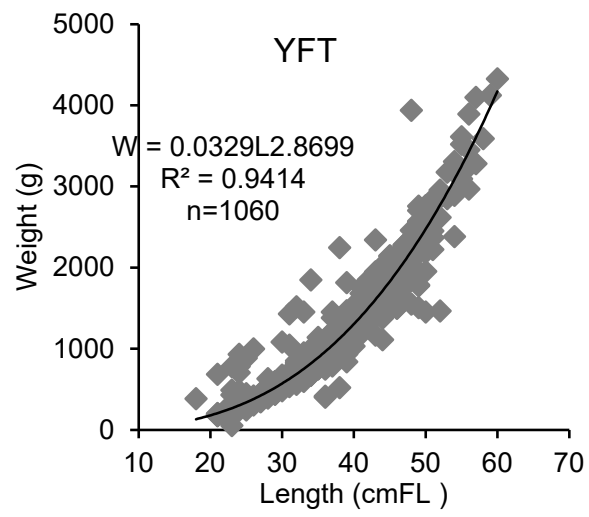

(b) 


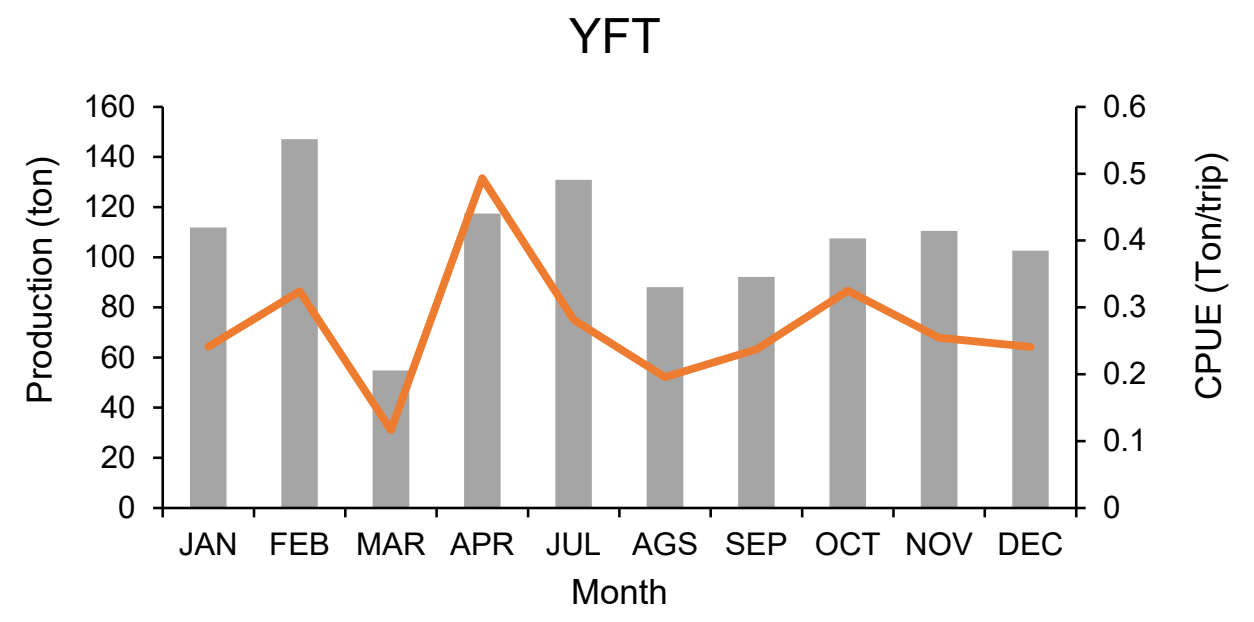

Production (ton) CPUE (ton/trip)

(c)

Fig. 5. YFT : (a) Length distribution ; (b) length-weight relationship; (c) CPUE.

Kawakawa (KAW) found in this study were 1.530 samples with a length distribution of 25-54 cmFL, dominant length $43 \mathrm{cmFL}$, average length $39 \mathrm{cmFL}$. Overall, the relationship between KAW length and weight follows the formula $\mathrm{W}=0,0111 \mathrm{~L}^{3,1319}$ with an $\mathrm{R}^{2}$ (coefficient of determination) $=0,9678$ (Fig. 6) and t-test results at the $95 \%$ level of confidence, it shows that the growth pattern of KAW is positive allometric $(b>3)$. This value means that the weight grows faster than the length, so the KAW looks more rounded or fatter. Analysis of catch per unit of effort or CPUE carried out on KAW obtained the highest in April.

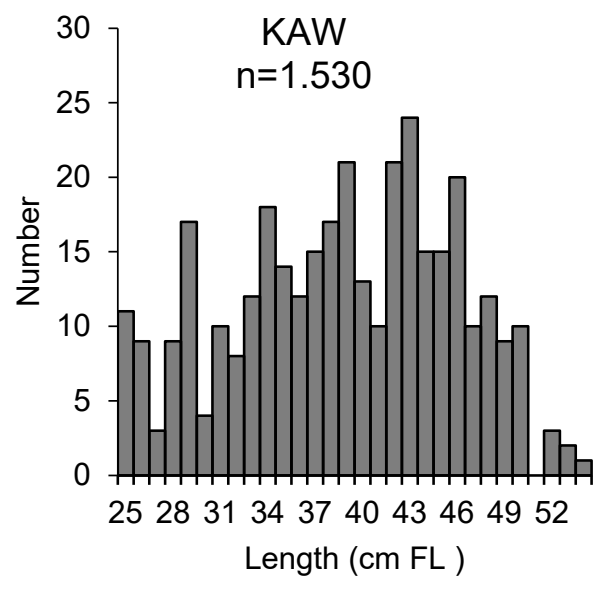

(a)

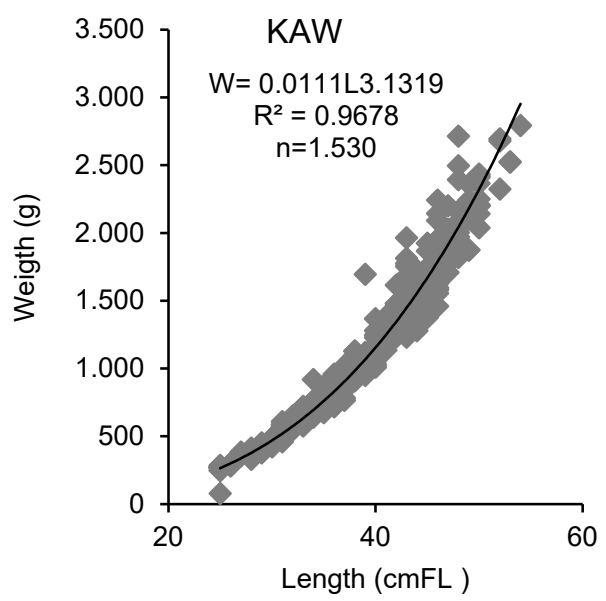

(b) 


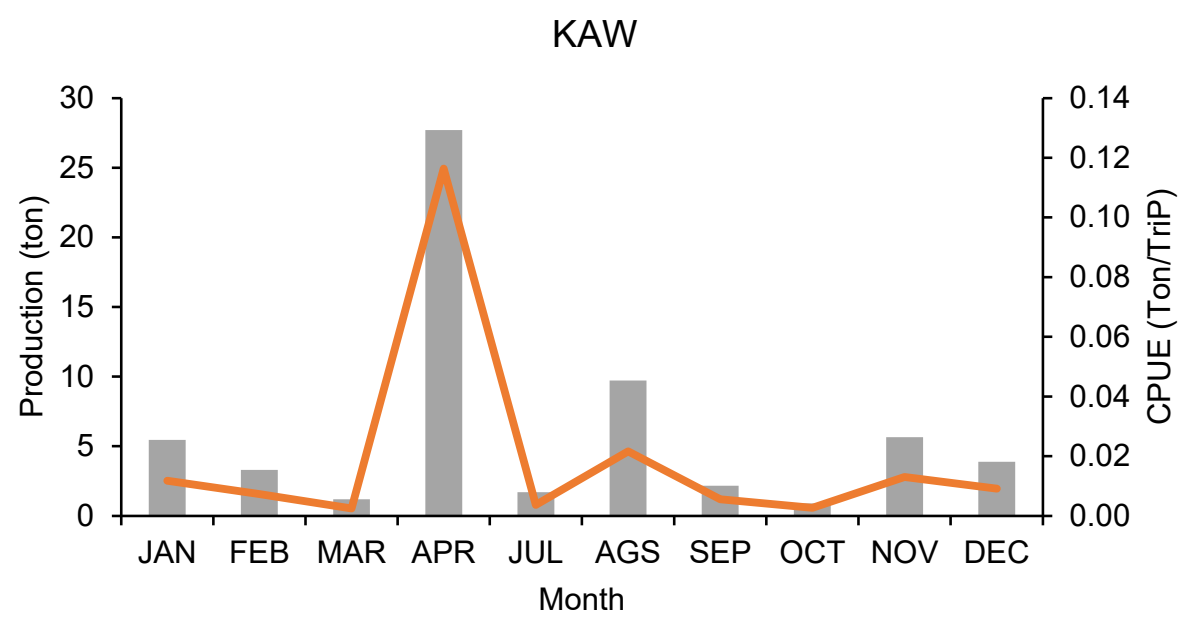

Production (ton) CPUE (ton/trip)

(c)

Fig. 6. KAW : (a) Length distribution; (b) length-weight relationship; (c) CPUE.

\section{Discussion}

The Sibolga Nusantara Fishery Port (PPN Sibolga) was built in 1993 and is one of the landing centers for small-scale tuna fisheries, especially on the west coast of North Sumatra. Weather conditions, in general, are the same as the weather around the equator, the wind is regular, hot, and there is much rainfall. The condition of the waters is relatively calm because it is protected by a group of islands such as Murshala Island, Situngkus Island, and other islands, so the potential for pelagic fish resources in Sibolga waters is quite potent. A purse seine is a fishing gear widely used in Sibolga waters, which is as big as other fishing gear [3]. A purse seine is capable of catching large amounts of pelagic fish, so that fishers are more dominant in using purse seine fishing gear in increasing the efforts made by fishermen. They were increasing the size of the vessels used [4], stating that fishing effort is a measure to produce several catches or a measure of the productivity of a fishing unit.

The fish targeted for catching a purse seine are pelagic fish clustered and close to the sea surface [5]. Skipjack is a schooling species commonly found under fish aggregating devices (FADs) and is often caught together with juvenile yellowfin tuna and bigeye tuna. The estimated TCT catches throughout 2020 show that skipjack tuna is the most caught, followed by frigate tuna, yellowfin tuna, and kawakawa. Skipjack tuna is a species of fish that is uniformly distributed in the Indian Ocean [6]. Skipjack tuna is a highly migratory species, being the main catch of fishermen in the Indian Ocean. Skipjack is one of the tremendous pelagic fishery resources that have the potential of the eastern waters of Indonesia. The species is listed as the least concerned species (LC) worldwide in the Red List of Threatened Species of the International Union for Conservation of Nature (IUCN) [7], and the determination of the inventory status in the Indian Ocean it remains green, or the stock is not overexploited [8]. The length range of skipjack tuna is caught between $18-60 \mathrm{cmFL}$. Overall the average value of skipjack tuna is still below the length of the first maturity (Lm), which is between $39.9-43.0 \mathrm{cmFL}[9,10,11]$. This is not a good indication related to sustainable fishing efforts. Even skipjack is a fish with a high level of resilience. However, in terms of 
management, it must also pay attention to the reproductive factors of the fish so that a high level of recruitment can be maintained every year.

The length range of yellowfin tuna is $18-60 \mathrm{cmFL}$ frigate tuna $17-44 \mathrm{cmFL}$, and kawakawa $25-54 \mathrm{cmFL}$. Purse seine fishing gear catches with by-catch more dominating than the main catch, the selectivity level of purse seine fishing gear is a fishing gear with a low selectivity level $[12,13]$. Most of the yellowfin tuna caught in southern Java are fish that have not been caught because they are less than $100 \mathrm{cmFL}$ in size. The structure of the length of the yellowfin tuna caught the longer to the east, the longer the size [14]. Most of the yellowfin tuna landed by purse seine were of a smaller size than predicted, YFT caught in the Indian Ocean are in the range of length $131-140 \mathrm{~cm}$ and weight $46-50 \mathrm{~kg}$ [15], and in the range of length 23-168 [14]. The fish suitable for catching is the size of the fish at first gonad maturity (length at first maturity $=\mathrm{Lm}$ ) [16]. The value of the first maturity size of yellowfin tuna in the Indian Ocean is about $100 \mathrm{cmFL}$ [17]. Indian ocean yellowfin tuna has been scored a high risk. The biomass is too low, and fishing mortality rates are too high for optimal harvesting, and the stock is at risk of being outside limit reference levels [8].

The Indian Ocean Scientific Committee in 2015 recommended that catches of yellowfin tuna be limited to $80 \%$ of 2014 levels. In 2016 and 2017, the IOTC adopted new measures to address the status of yellowfin tuna. Under these measures, nations reduced their gillnet and longline catches by $10 \%$, pole and line-handling by $5 \%$, and purse seine catch by $15 \%$ from 2014 levels $[8,18]$. Frigate tuna is considered one of the most valuable fish on the Indonesian market, especially Sibolga and the adjacent waters. The exploitation of this merchandise increases every year, and it is transported mainly by purse seiners. Frigate tuna distributed from $1945 \mathrm{~cm}$ in length with an average length of $32.91 \mathrm{~cm}$ in length [19]. The length of the first catch (Lc) of fish with a $31.7 \mathrm{cmFL}$ seine net. The frigate tuna fishing rate (E) is considered relatively low $(\mathrm{E}=0.37)$. There is the possibility of increasing the fishing effort by around $30 \%$ of the actual level. Kawakawa is one of the essential catches by fishers in the Indian Ocean west of Sumatera [20]. The total instantaneous annual mortality rate (Z) was 2.40 / year, the natural mortality (M) was 1.07 / year, and the fishing mortality (F) was 1.33 / year. The exploitation rate $(\mathrm{E}=0.55)$ indicated that Kawakawa was moderately exploited in this area.

Indonesia already has a national tuna management plan to guide relevant central and regional government institutions for their annual tuna-related activities. The development and implementation of the framework for the fishing strategy is a priority action of the National Tuna Management Plan (NTMP) for Tuna and Neritic Species and the related action plans established in the Ministerial Decree for Marine Affairs and Fisheries of the Republic of Indonesia. Number 107 / KEPMENKP / 2015.

The CPUE results for yellowfin tuna, skipjack, kawakawa, and frigate tuna fluctuate every month but have the same highest CPUE value in April. Increased fishing effort does not guarantee an increase in catches and CPUE values. The catch change in a particular month due to the influence of fish presence and the success rate of fishing operations. This phenomenon also causes the CPUE value to fluctuate. The tuna fishing season in Sibolga waters does not correspond to the tuna fishing season in other areas. It can be seen in the close relationship between extreme fluctuations and total production due to environmental changes in these waters.

\section{Conclusion}

The estimated value of the catch obtained from 4.122 vessels that landed with 185 vessels sampled, namely: skipjack tuna (Katsuwonus Pelamis) (SKJ) of 232,823 tons, yellowfin tuna (Thunnus albacares) (YFT) of 23,682 tons, frigate tuna (Auxis thazard) (FRI) is 40,949 tons, and Kawakawa (Euthynnus affinis) is 1,374 tons. As of 6.149 samples, Skipjack tuna have 
length class between 18-60 cmFL with positive allometric growth, CPUE highest in April $(3,65)$, and lowest in August (1.7). Frigate tuna of 1.619 samples with a lengthy class between 17-44 cmFL with positive allometric growth, CPUE highest in October (1.43) and lowest in December (0.07). Yellowfin tuna of 1.060 samples with a lengthy class between 18-60 cmFL with negative allometric growth, CPUE highest in April $(0,49)$ and lowest in March $(0.11)$. Kawakawa of the 1.530 samples has a length class between 25-54 cmFL with positive allometric growth, with the highest CPUE in April (0.12) and lowest in March and July (0.01).

\section{Acknowledgments}

This paper is part of a monitoring program Research Institute of Tuna Fisheries. The author says thanks to Mr. Musda Sibarani and all PPN Sibolga employees for their contribution to data collection.

\section{References}

1. T. N. Utami, Fishery Commoditie (in Bahasa Indonesia) (UB Press, Malang, 2018)

2. Wijopriyono, D. Nugroho, B. Sadhotomo, JPPI 18, 4 (2016)

3. PPN Sibolga, Sibolga VAT annual report (Ministry of Marine Affairs and Fisheries Republic of Indonesia, Sibolga, 2018)

4. S.M. McCluske, R.L. Lewinson, Fish and Fish. 9, 2 (2008)

5. S. Dueri, B. Faugeras, O. Maury, Ecological Modeling 245, 41-54 (2012)

6. M. I. Effendie, Fisheries biology (in Bahasa Indonesia) (Yayasan Pustaka Nusantara, Yogyakarta, Indonesia, 2002)

7. IUCN, The IUCN red list of threatened species (2019)

8. IOTC, Report of the $20^{\text {th }}$ session of the IOTC scientific committee (IOTC, Seychelles, 2017)

9. RITF, Research on biological characteristics, population dynamics and structure, and exploitation levels of tuna fisheries resources in the Indian Ocean (FMA 572 and 573, 2017)

10. I. Jatmiko, H. Hartaty, A. Bahtiar, BAWAL 7, 2 (2015)

11. O.I. Timohina, E.V. Romanov, IOTC Proceedings 9, 247 (1996)

12. A. Rambun, Sunarto, I. Nurruhwati, Perikan. Kelaut. 7, 97 (2016)

13. I.N. Rosyidah, A. Farid, W.A. Nugraha, JIPK 3, 1 (2011)

14. M. Agustina, B. Setyadji, P.A.R.P. Tampubolon, BAWAL. 11, 3 (2019)

15. S. Triharyuni, B.I. Prisantoso, Saintek Perikanan 8, 1 (2012)

16. M. Jamal, M.F.A. Sondita, J. Haluan, B. Wiryawan., J. Natur. Indones. 14, 1 (2011)

17. G. Zhu, L. Xu., Y. Zhou, X. Dai., Acta Ichthyologica et Piscatoria 38, 2 (2008)

18. IOTC, On harvest control rules for skipjack tuna in the IOTC Area of Competence (IOTC, Seychelles, 2016)

19. H. Hartaty, S. Bram, BAWAL. 8, 183 (2016)

20. I. Jatmiko, R.K. Sulistyaningsih, D. Nugroho, BAWAL. 6, 2 (2014) 